This item was submitted to Loughborough's Research Repository by the author.

Items in Figshare are protected by copyright, with all rights reserved, unless otherwise indicated.

\title{
Impacts of gravel jetting on the composition of fish spawning substrates: Implications for river restoration and fisheries management
}

PLEASE CITE THE PUBLISHED VERSION

http://dx.doi.org/10.1016/j.ecoleng.2017.06.057

PUBLISHER

(C) Elsevier

VERSION

AM (Accepted Manuscript)

\section{PUBLISHER STATEMENT}

This work is made available according to the conditions of the Creative Commons Attribution-NonCommercialNoDerivatives 4.0 International (CC BY-NC-ND 4.0) licence. Full details of this licence are available at: https://creativecommons.org/licenses/by-nc-nd/4.0/

\section{LICENCE}

CC BY-NC-ND 4.0

\section{REPOSITORY RECORD}

Basic, Tea, J. Robert Britton, Stephen P. Rice, and Andrew G. Pledger. 2019. "Impacts of Gravel Jetting on the Composition of Fish Spawning Substrates: Implications for River Restoration and Fisheries Management". figshare. https://hdl.handle.net/2134/25970. 
1 Impacts of gravel jetting on the composition of fish spawning substrates:

2 implications for river restoration and fisheries management

3

4 Tea Bašić ${ }^{1}$

5 J. Robert Britton ${ }^{1}$

6 Stephen Rice ${ }^{2}$

7 Andrew Pledger $2,3,4$

8

$9{ }^{1}$ Department of Life and Environmental Sciences, Faculty of Science and Technology,

10 Bournemouth University, Poole, Dorset, BH12 5BB, UK.

$11{ }^{2}$ Geography Department, Loughborough University, Epinal Way, Loughborough,

12 Leicestershire, LE11 3TU, UK.

13 '3niversity Centre Reaseheath, Reaseheath, Nantwich, CW5 6DF, UK.

$14{ }^{4}$ AP Environmental Solutions, 15 Hillside, Sawston, Cambridge, UK, CB22 3BL.

15

16 Running title: Gravel jetting impacts on spawning gravels

17

18 Keywords: Gravel jetting; Barbus barbus; Spawning gravels; Habitat management.

19 Corresponding author: Tea Bašić; +44(0)7552637388;

20 TBasic@bournemouth.ac.uk;

21 Bournemouth University, Talbot campus, Christchurch House, Poole, Dorset, BH12

$225 B B, U K$. 


\section{Abstract}

24 Fine sediments can impact river biota, with egg and larval stages of lithophilic fish 25 particularly sensitive to deposition of sand- to clay-sized particles ('fines') in spawning 26 gravels. Mitigation and restoration methods include jetting to cleanse gravels of fines.

27 Despite wide application, impacts of jetting on gravel composition and quality have rarely been quantified. Here, gravel jetting impacts on sediment composition in the River Great Ouse (UK), were tested during an in-situ experiment completed at riffle (55.6 $\left.\pm 13.4 \mathrm{~m}^{2}\right)$ and patch $\left(0.3 \mathrm{~m}^{2}\right)$ scales to determine its magnitude and persistence on surface and subsurface substrate conditions. Before-after (riffle) and control-impact (patch) designs were used, with bedload sediment traps installed downstream of experimental patches to investigate the sediments mobilised during jetting. At the riffle scale, surface grain size was significantly altered; fines were removed resulting in coarser and better-sorted sediments. Similar patterns were detected at the patch scale, although sediment sorting was not significantly altered. Despite reduced fine sediment content of subsurface gravels at the riffle scale, the overall grain size composition was not significantly altered. At the patch scale, no subsurface improvements were detected. Temporally, at the riffle scale, no changes in surface or subsurface sediments lasted more than 12 months; patch scale changes generally persisted for less than 3 months.

41 Thus, whilst gravel jetting could improve spawning gravel quality for surface spawning fishes, including European barbel Barbus barbus, its effects are short-lived. Because subsurface sediments are not affected by gravel jetting, the benefits are limited for reddbuilding fishes, such as salmonids. Consequently, reducing fine sediment delivery to rivers, such as by changes in agricultural practices, is more sustainable for managing excessive river sedimentation. 


\section{Introduction}

48 In-stream degradation of river functional habitats is amongst the most-studied of all

49 forms of freshwater degradation (Morandi et al. 2014), with deterioration in substrate

50 quality associated with global declines in freshwater biodiversity (Hancock 2002). The

51 importance of river substrata includes its provision as functional habitat for the

52 development of many taxa (Geist 2011; Hancock 2002; Palmer et al. 1997; Sternecker

53 at al. 2013a). Processes and activities that impact bed sediment composition, such as

54 delivery of excess fine sediment ( $\leq 2 \mathrm{~mm}$; 'fines'), can negatively impact riverine biota

55 (Dudgeon et al. 2006; Kemp et al. 2011; Wood and Armitage 1997). For example, reproductive success and recruitment of lithophilic fishes can be influenced by fine sediment ingress that alters the composition of spawning gravels (Kemp et al. 2011). Fines content in spawning gravels affects interstitial flows and so impacts oxygen

59 permeation, metabolic waste removal and fry emergence (e.g. Kemp et al. 2011;

60 Pattison et al. 2015; Sear et al. 2016). Consequently, river restoration methods often

61 focus on reducing fines content in spawning gravels with the aim of improving 62 reproductive success to enhance fish populations (Bernhardt et al. 2005; Giller 2005;

63 Wood and Armitage 1997).

64

65 A variety of methods have been used to reduce the fines content of spawning gravels, 66 including gravel augmentation, placement of in-stream structures (e.g. woody debris,

67 boulders etc.) and gravel cleaning (Wheaton et al. 2004a, 2004b). Gravel augmentation 68 involves replenishing depleted or replacing degraded sediments, increasing spawning 69 substrate availability (McManamay et al. 2010; Merz and Chan 2005) and/or suitability 70 (Pander et al. 2015; Pulg et al. 2013; Sarriquet et al. 2007). Hydraulics, and so substrate 
71 conditions, can be manipulated using in-stream structures such as artificial log steps,

72 boulders and woody debris (Michel et al. 2014; Palm et al. 2007; Pander et al. 2015).

73 These measures can mitigate some of the negative effects resulting from fine 74 sedimentation by increasing hyporheic water exchange (Michel et al. 2014). In addition, 75 gravel cleaning techniques, such as substrate raking, typically involve the mechanical 76 bioturbation of sediments to promote fine sediment mobilisation (Meyer et al. 2008) and 77 can help restore spawning gravels of lithophilic fishes (Pander et al. 2015; Pulg et al. 78 2013; Sternecker et al. 2013b).

80 Despite wide application, in practice many mitigation projects are inhibited by 81 scientifically weak approaches, without specific objectives, post-monitoring evaluations 82 and consideration of landscape processes that provide the context for specific 83 sedimentation problems (Bond and Lake 2003; Wheaton et al. 2004a, 2004b). Most 84 studies also report results from reach-scale $(<1 \mathrm{~km}$ restored river section) projects that 85 lack a temporal component (Palmer et al. 2010; Pander and Geist 2013). Equally, some 86 projects lack pre-restoration assessments, a component crucial to understanding the 87 longevity of effects through time and/or space (Morandi et al. 2014; Wheaton et al. 88 2004a; Wheaton et al. 2004b). Thus, studies that utilise robust experimental designs are 89 integral for understanding the factors that contribute to successful restoration (Palmer et 90 al. 2007).

91

92 Gravel jetting, a technique to remove fines from gravels and provide enhanced 93 spawning substrates for fish, has been widely applied in British rivers (Hendry et al. 94 2003). Despite this, only two studies report the impacts of gravel jetting on spawning 
95 substrates (Shackle et al. 1999; Twine 2013). Both studies found gravel jetting 96 decreased percentage fines within subsurface sediments (Shackle et al. 1999; Twine 97 2013). However, both lacked replication and temporal perspectives. Whilst gravel 98 jetting might improve local spawning substrate conditions, the process could potentially 99 have negative consequences for downstream habitats and biota by releasing fine 100 sediments (Kemp et al. 2011; Sternecker et al. 2013b). Also, gravel jetting loosens 101 fluvial substrates, removing naturally developed stabilising sediment structures that 102 might reduce critical entrainment thresholds and increase bed mobility under ambient 103 and high flows. This has potential implications for egg-to-emergence survival if excess 104 scour exposes egg pockets (Buffington et al. 2004; Hassan et al. 2015). Shackle et al. 105 (1999) observed increased rates of sedimentation downstream of restored areas, but 106 failed to quantify some potential negative impacts of different gravel cleaning methods 107 on downstream habitats. Other studies have reported increased sedimentation 108 downstream of restoration works (Pander et al. 2015; Sternecker et al. 2013b). 109 Specifically, fine sediment accrual was observed in close proximity to restored sections 110 and it could be assumed that this would create problems for downstream habitats by, for 111 example, causing siltation of gravels. Therefore, while there is some evidence to suggest 112 that jetting can be of local value, its benefits are not unequivocally established and the 113 activity is not risk-free, such that jetting practices require careful assessment.

115 Consequently, this study utilised an experimental approach under field conditions to 116 quantify the effects of gravel jetting on fish spawning grounds. Given the paucity of 117 knowledge on gravel improvement schemes for non-salmonid fishes (Kemp et al. 2011), 118 the focus was on the enhancement of gravels utilised for spawning by the cyprinid 
119 European barbel Barbus barbus in the middle reaches of the Great Ouse River, Eastern

120 England. Barbus barbus was used as the focal species as it is a typical non-salmonid

121 lithophile that is a flag species for indicating good ecological status (Britton and Pegg

122 2011). It is also a potentially powerful zoogeomorphological agent (Pledger et al. 2014,

123 2016) in rivers. Their fisheries also have relatively high socio-economic value (Britton

124 and Pegg 2011) and so there is a management requirement for their populations to be

125 sustainable. In addition, by restoring B. barbus spawning areas, other fishes should also

126 benefit through improved spawning substrata (e.g. S. cephalus; Arlinghaus and Wolter

127 2003; Balon 1975; Pinder 1997) and foraging habitats (Merz and Chan 2005; Mueller et

128 al. 2014). The objective was to determine changes in sediment condition and mobility

129 caused by gravel jetting, by measuring (1) surface sediment composition at riffle and 130 patch scales (D5, D50 and D95 percentiles, mean, sorting (spread of the grain size

131 distribution), skewness (measure of asymmetry of the grain size distribution curve),

132 kurtosis (shape of the curve); Bunte and Abt 2001); (2) subsurface sediment

133 composition at riffle and patch scales (D5, D50, D95, mean, sorting, skewness, kurtosis

134 and sand and silt contents) and percentage of organic matter at patch scale; (3) longevity

135 of gravel jetting effects: composition of surface and subsurface sediments after 12

136 months (riffle scale) and after 3 and 9 months (patch scale); and (4) quantity and

137 composition of any sediment washed from the bed during patch-scale jetting.

138

\section{2. Materials and Methods}

\section{$140 \quad 2.1$ Study sites}

141 In the summer (August-September) of 2014 and 2015, experimental work was

142 conducted on cyprinid fish spawning gravels in the middle River Great Ouse, eastern 
143 England (Figure 1). The Great Ouse has a catchment area of $8600 \mathrm{~km}^{2}$, receives low 144 mean annual rainfall ( $<63 \mathrm{~cm} \mathrm{y}^{-1}$; Pinder et al. 1997) and is predominately 145 groundwater-fed (Neal et al. 2000). It is highly regulated in its lower reaches for the 146 purposes of flood and land management (Garner 2010; Pinder 1997; Pinder et al. 1997) 147 and is impacted generally by agricultural inputs (Neal et al. 2000). In the last 20 years, 148 to improve fish populations and the fisheries they support, the Environment Agency, the 149 fisheries regulatory authority of England, have used a combination of stocking with 150 hatchery-reared B. barbus (Bašić and Britton 2016) and habitat improvement schemes, 151 primarily gravel jetting of spawning gravels.

152

153

154

155

156

157

158

159

160

161

162

163

164

165

166 


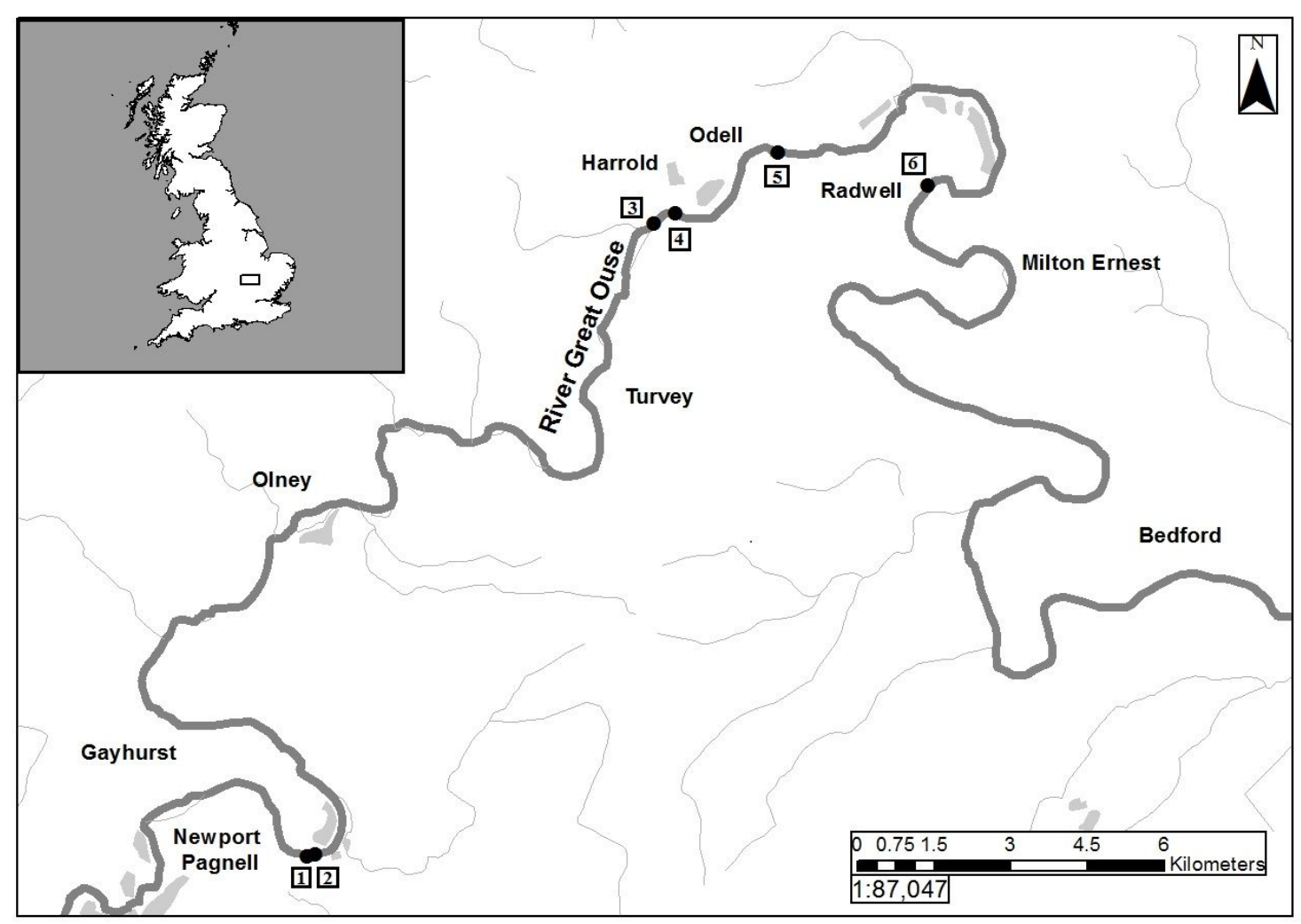

168 Figure 1. Location of the study reach in the UK, highlighting sampled riffles in the River Great Ouse between Newport Pagnell and

169 Bedford. Labelled black dots correspond to the locations of sites at: 1 - U/S Newport Pagnell 2, 2 - D/S Newport Pagnell, 3 - Harrold weir,

1704 - U/S Harrold bridge, 5 - U/S Odell, 6 - Radwell bridge, sampled during riffle-scale ( $n=5$; sites 1-5; riffle scale) and patch-scale (n = 3;

171 sites 3, 5 and 6; patch scale) experiments (Ordnance survey 2005; Ordnance survey 2015). 
172 The experimental sites were selected using a strict set of criteria; they needed to be 173 wade-able under base-flow conditions and be either natural spawning sites of target 174 cyprinid lithophiles like B. barbus (cf. Twine 2013), or be representative of spawning 175 sites in terms of their hydraulic (water depth: $0.12-0.88 \mathrm{~m}$; near-bed flow velocity: $1760.16-0.96 \mathrm{~ms}^{-1}$; mean flow velocity: $0.2-1.07 \mathrm{~ms}^{-1}$ ) and substrate conditions (surface 177 grain size: 2 - 60 mm) (Banarescu and Bogutskaya 2003; Melcher and Schmutz 2010).

178 The experiment was completed at two spatial scales; riffle $\left(55.55 \pm 13.35 \mathrm{~m}^{22}\right)$ and 179 patch $\left(0.25 \mathrm{~m}^{2}\right.$ : i.e. small areas within a riffle), to quantify how jetted area influences 180 the magnitude and temporal persistence of restoration effects. The Environment Agency 181 typically restores smaller patches of riffles during jetting. Therefore, patches always 182 retained the same size of $0.25 \mathrm{~m}^{2}$, whereas the size ranges of riffles utilised in the experiment varied from $26.88 \mathrm{~m}^{2}$ to $98.04 \mathrm{~m}^{2}$.

In 2014, five of these selected at random and samples of surface and subsurface 186 sediments were taken pre- and post-gravel jetting at the riffle scale (Figure 2a). A 187 before-after experimental design was selected due to confined riffle sizes, preventing 188 bisection of riffles into spatially independent control and treated areas. This ensured 189 jetting activities would not influence quantitative results from control sections of riffles.

190 The patch scale experiment in 2015 adopted a control impact design with post treatment 191 sampling at three of the riffle sites and utilised $0.5 \times 0.5 \mathrm{~m}$ areas which were either 192 jetted (treatment) or not jetted (control) (Figure 2b). This allowed for monitoring of 193 temporal changes during the post-restoration period, while controlling for the different 194 environmental impacts. The three sites used for the patch scale experiments were 195 Harrold weir, U/S Odell and Radwell (Figure 2a, b), selected on the 
196 basis of their size and similarity in flow, depth and surface sediment characteristics.

197 This was to ensure quantitative findings were not influenced either by the proximity of

198 control and treated patches or substantial difference in flow/sediment conditions.

199 Before-after design was not utilised at the patch scale, because collecting a core sample

200 before jetting at a smaller scale would influence bed stability during patch-scale jetting,

201 hence outcomes of the procedure.

202

203

204

205

206

207

208

209

210

211

212

213

214

215

216

217

218

219

220 

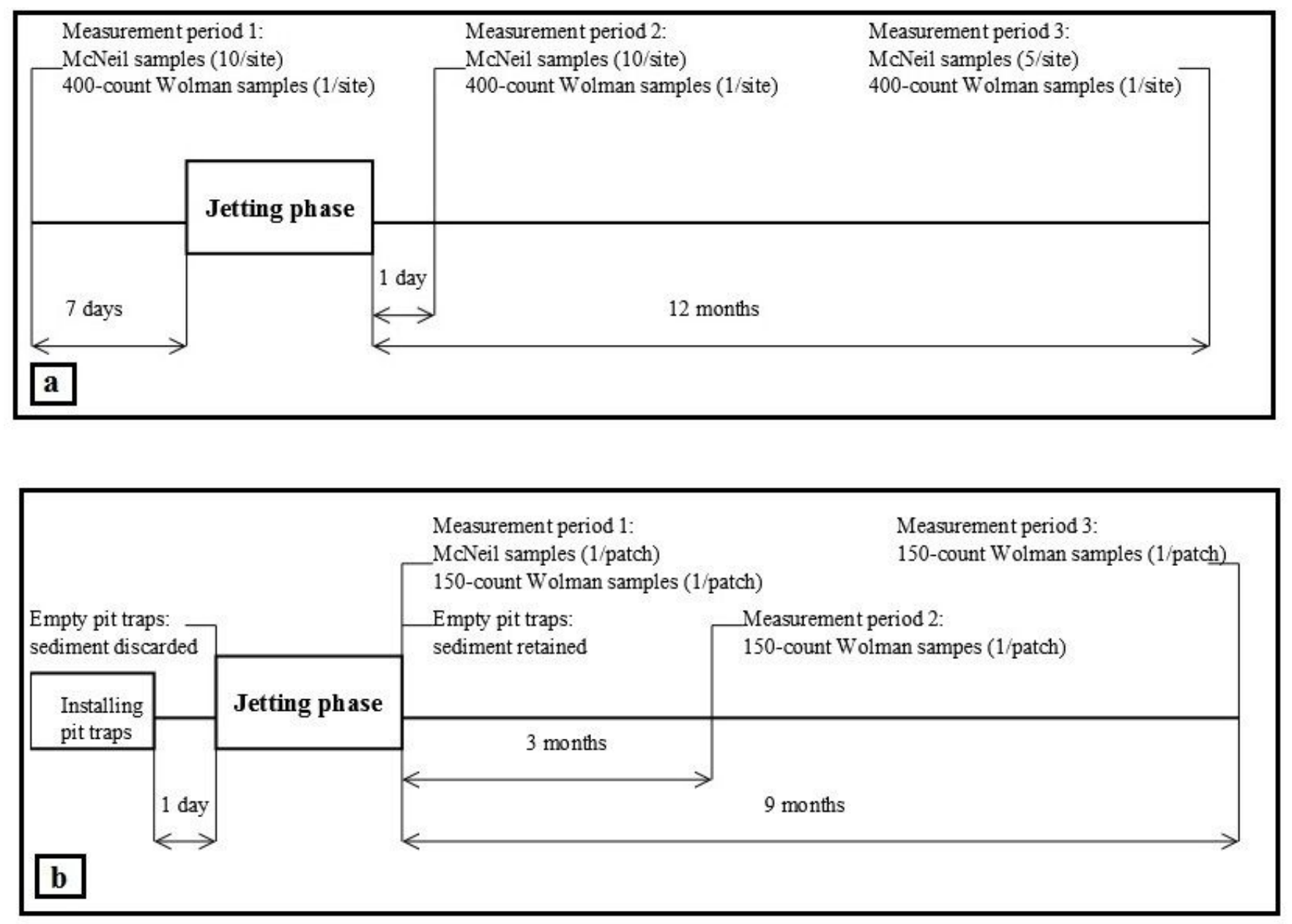

222 Figure 2. Schematic diagrams presenting the experimental procedure for a) riffle-scale and b) patch-scale experiments, performed in 223 2014/2015 and 2015/2016, respectively. 
225 Riffle-scale jetting took different lengths of time depending on riffle size (range = 45 $226180 \mathrm{~min}$ ), but effort per person and unit area was consistently applied across all sites. 227 For consistency, each site was jetted by three operators, who started at the upstream end 228 of the riffle and worked downstream. During the experimental period, no flood events 229 were recorded and in each case, pre- and post-treatment sampling was conducted 7 days before and 1 day after gravel jetting, respectively (Figure 2a). It was thus assumed that measured differences between conditions before and after the jetting phase were the direct result of gravel jetting.

234 One year later, during patch-scale jetting three control and three treatment patches were selected that were located upstream (control) and downstream (treatment) of each other, at each of the three sites. This was to ensure an adequate degree of replication. Patches were spaced $3 \mathrm{~m}$ apart in each direction to ensure spatial independence. Prior to jetting

238 the treatment patches, two plastic bedload slot samplers $(0.28 \times 0.18 \times 0.15 \mathrm{~m})$ were 239 installed downstream of each patch so they were flush and level with the bed surface, 240 and were used to assess the quantity and composition of sediment $(>0.064 \mathrm{~mm})$ 241 released from the bed and transported as bedload during jetting. The treatment patches 242 were then exposed to jetting by a single operator for a fixed 15-minute time period 243 (Figure 2b). Rigid plastic inserts, placed within each of the slot samplers, were emptied 244 during and after the jetting phase and any collected sediment was retained for laboratory 245 analysis (Figure 2b). 

scales

249 At the riffle scale, surface grain-size distributions were determined before and after 250 gravel jetting using 400-count Wolman samples (Rice and Church 1996), with a lower 251 truncation limit set at $<2 \mathrm{~mm}$. To investigate the persistence of gravel jetting effects, 252 measurements of surface sediment characteristics were made at four of the sites 253 (excluding U/S Newport Pagnell, due to limited access), approximately 12 months after 254 jetting in August 2015. Again, 400-count Wolman samples were used to assess surface 255 grain size distributions (Figure 2a).

257 At the patch scale, a 150-count Wolman sample was collected post-jetting from each of 258 the treatment and control patches (Figure 2b). During patch-scale assessments, grains were carefully selected, sized and returned to their original locations. A systematic approach was adopted when selecting grains that ensured clasts were not reselected. All

261 control and treatment patches were monitored after 3 and 9 months (Figure 2b) using

262 150-count Wolman samples. This was to specify the longevity of gravel jetting impacts

263 within one year, based on the results derived from the riffle scale experiment ( $c f$.

264 Results). Monitoring patches 6 months post jetting was not feasible due to high flows 265 and so dangerous working conditions. The experiment was terminated after 9 months as 266 no significant change was observed between pre- and post-jetting conditions for any of 267 the parameters (cf. Results). 
269 From surface samples collected at both spatial scales, D5, D50, D95 percentiles and 270 mean, sorting, skewness and kurtosis were obtained using Trask’s (1932) graphic mixed

271 approach (Bunte and Abt 2001). These data were used to address objectives (1) and (3).

272

2732.4 Impacts of gravel jetting on subsurface sediment composition at different temporal 274 scales

275 At the riffle scale, 10 samples of subsurface sediments were collected per site using a 276 McNeil sampler (core volume $\approx 0.005 \mathrm{~m}^{3}$; McNeil and Ahnell, 1964) and Koski plunger 277 before and immediately after gravel jetting. The McNeil sampler provides a robust 278 sample of bed material, including fine sediments, at inundated, but shallow sites. 279 Twelve months later, an additional 5 McNeil samples were collected from each of the 280 sites. Each subsurface sample was dried and sieved into whole-phi size fractions separately, using an electronic shaker and sieve stack before weighing.

282

283 At the patch scale, one McNeil sample was collected from each of the treatment and 284 control patches post-jetting (Figure 2b). Longevity of jetting effects at the patch scale 285 was monitored for surface sediments alone because no significant changes to subsurface properties were detected and so expected, immediately and 3 months after jetting, respectively.

289 D5, D50, D95 percentiles and mean, sorting, skewness and kurtosis were calculated as 290 described in Section 2.3. Additionally, fine sand $(0.063 \mathrm{~mm}-2 \mathrm{~mm})$ and silt $(\leq 0.063$ $\mathrm{mm}$ ) contents were determined, as these size fractions are recognised as having 292 significant detrimental impacts on bed permeability, oxygen supply and thus in-situ egg 
survival and larval emergence (Bryce et al. 2010; Franssen et al. 2014; Lapointe et al.

294 2005; Meyer 2003; Sear et al. 2016). Percentage organic matter was measured only for

295 patch-scale subsurface sediments via Loss on Ignition (LOI hereafter; CEN 2007), 296 where a $10 \mathrm{~g}$ subsample of fine sediment $(\leq 2 \mathrm{~mm})$ was taken from each dried and 297 sieved sample and further dried in an oven for $24 \mathrm{~h}$ at $100{ }^{\circ} \mathrm{C}$. Each sample was then 298 weighed to measure the pre-ignition mass $\left(m_{p r e}\right)$. Samples were subsequently placed in a 299 furnace for $3 \mathrm{~h}$ at $550{ }^{\circ} \mathrm{C}$ before determining their post-ignition mass $\left(m_{\text {post }}\right)$. The 300 percentage of organic matter in each sample was determined using the equation (1).

301

$302 \%$ organic matter $=\left(\frac{\text { mpre-mpost }}{\text { mpre }}\right) * 100$

303 Subsurface sediments data were used to address objectives (2) and (3).

304

2.5 Impact of gravel jetting on the size distribution and mass of transported bedload at

306 the patch scale

307 Bedload samples collected downstream of treatment and control patches during the

308 jetting phase were dried and sieved into whole-phi size fractions using an electronic 309 shaker and sieve stack before weighing. Data derived from these samples were 310 compared to identify the immediate impacts of jetting on bedload transport (Figure 2b).

312 D5, D50, D95 percentiles and statistical parameters (mean, sorting, skewness, kurtosis)

313 were derived from bedload sediments, along with fine sand, silt and organic matter

314 content. Also, total transported mass data were extrapolated to the riffle scale by 315 multiplying the average transported mass with corresponding riffle area, providing an 
316 estimate of the total mass of sediment purged from each riffle during the jetting phase.

317 Bedload sediment data were used to address objective (4).

318

3192.6 Data analysis

320 At the riffle scale, changes in surface and subsurface sediment composition in time due

321 to gravel jetting were assessed using linear (LMM) and generalized linear mixed models

322 (GLMMs, package lme4; Bates et al. 2015). This approach accounted for the random

323 effect of site for surface and subsurface sediments and pseudoreplication of subsurface

324 sediments (5 or 10 samples per site). Prior to any analyses, residuals from each data set

325 were tested for normality using the MASS package (Venables, and Ripley 2002) in R

326 3.2.2 (R Development Core Team 2011). In the case of normally distributed residuals, model parameters were estimated using restricted maximum likelihood in linear mixed models to account for crossed random effects, small sample sizes and unbalanced design. In the case of log normal distributions, data were analysed using the flexible,

330 penalised, quasi-likelihood method (family-Gaussian; link-log) that is suitable for over331 dispersed data, crossed random effects and unbalanced design. However, where the mean of the response variable was below 5, the estimate was biased (Bates 2010; Bolker et al. 2009), so a Laplace approximation (family-Gaussian; link-log) was used (Bates 2010; Bolker et al. 2009). To test for differences in sand and silt content at the riffle scale, Laplace approximation with binomial logistic regression models (family-

336 binomial; link-logit) was used, with weight argument specified as the total mass of 337 sediment analysed for each sample. 
339 At the patch scale, changes in surface sediment composition in time as a result of gravel

340 jetting were analysed using linear (LMM) and generalized linear mixed models (GLM-

341 family-Gaussian; link-log and family-binomial; link-logit) to account for temporal

342 dependency of the data by using repeated measure as a random effect on the intercept.

343 Changes in subsurface sediment composition through gravel jetting were assessed using

344 linear (LM) and generalized linear models (GLM-family-Gaussian; link-log and family-

345 binomial; link-logit), as no spatial or temporal dependency was assumed between

346 patches. However, in cases of data over-dispersion, each sample was classed as a

347 random effect on the intercept in mixed models.

349 At both spatial scales, where significant effects were detected, pairwise comparisons of covariate adjusted means were performed using least-squares means with Dunnett adjustment for $P$ values for multiple independent comparisons of treatments with the control.

\section{Results}

3.1 Impacts of gravel jetting on surface sediment composition at different temporal scales

357 At the riffle scale, gravel jetting had a significant impact on the D5 (LMM; $P<0.01$ ), D95 (GLMM; $P<0.01)$, mean (LMM; $P<0.01)$ and degree of sediment sorting (LMM; $P<0.01$ ) (Table 1a). As a function of gravel jetting, mean D5, D50 and D95

360 values for surface sediments increased significantly (Table 1b; Figure 3) indicating a

361 coarsening of the sediment surface (Table 1b; Figure 3). Even though sediments were

362 already well sorted prior to jetting, sediment sorting was increased significantly by 
363 jetting (Table 1b; Figure 3). However, kurtosis (LMM; $P$ > 0.05) and skewness (LMM;

$364 P>0.05$ ) did not change (Table 1a). Specifically, sediments derived before and after the

365 jetting phase maintained nearly symmetrical and leptokurtic grain size distributions,

366 characterised by clustering around the means and small standard deviations (Figure 3).

367

368 There were no significant differences in any of the surface percentiles when comparing 369 conditions before and 12 months after the jetting phase (Table 1b; Figure 3). A similar 370 pattern was observed for mean, sorting, skewness and kurtosis values, with no 371 significant differences found between before jetting and 12 months after jetting (Figure $3723)$.

373

374

375

376

377

378

379

380

381

382

383

384

385 
Table 1 Outputs from linear mixed models testing for differences at the riffle scale in surface sediment parameters: a) final models; and b) pairwise comparisons; where: 1) pre- and 24 hours post-jetting; and 2) pre- and 12 month post-jetting. Site was specified as a random effect on the intercept. Mean differences are from estimated least-square means (difference significant at $* P<0.05$ and $* * P<0.01$ ).

391

a)

\section{Final models}

D5 $\sim$ Treatment $+(1 \mid$ Site $)(\text { AIC }=71.20 \text {; log likelihood }=-30.60 ; P<0.05)^{*}$

D50 Treatment $+(1 \mid$ Site $)\left(\right.$ AIC $=61.22 ; \log$ likelihood $\left.=-24.01 ; P<0.01^{* *}\right)$

D95 Treatment + (1|Site) (family - Gaussian (link-log); penalized quasilikelihood; AIC = NA;

$\log$ likelihood $=$ NA; $\left.P<0.01^{* *}\right)$

Mean $\sim$ Treatment $+(1 \mid$ Site $)\left(\right.$ AIC $=56.31 ; \log$ likelihood $\left.=-23.15 ; P<0.01^{* *}\right)$

Sorting $\sim$ Treatment $+(1 \mid$ Site $)\left(\right.$ AIC $=-47.26$; log likelihood $\left.=28.63 ; P<0.01^{* *}\right)$

Skewness $\sim$ Treatment $+(1 \mid$ Site $)($ AIC $=-35.42 ; \log$ likelihood $=22.71 ; P>0.05)$

Kurtosis $\sim$ Treatment $+(1 \mid$ Site $)($ AIC $=-62.93 ; \log$ likelihood $=36.46 ; P>0.05)$

\section{b)}

\begin{tabular}{lll}
\hline Metric & Mean difference & 2 \\
& $\mathbf{1}$ & $-0.11 \pm 1.26, P>0.05$ \\
\hline D5 & $-3.28 \pm 1.15, P<0.05^{*}$ & $-0.60 \pm 0.69, P>0.05$ \\
D50 & $-7.24 \pm 0.64, P<0.01^{* *}$ & $0.02 \pm 0.05, P>0.05$ \\
D95 & $-0.12 \pm 0.04, P<0.05^{*}$ & $-0.56 \pm 0.67, P>0.05$ \\
Mean & $-6.66 \pm 0.62, P<0.01^{* *}$ & $0.01 \pm 0.02, P>0.05$ \\
Sorting & $-0.06 \pm 0.02, P<0.05^{*}$ & \\
\hline
\end{tabular}



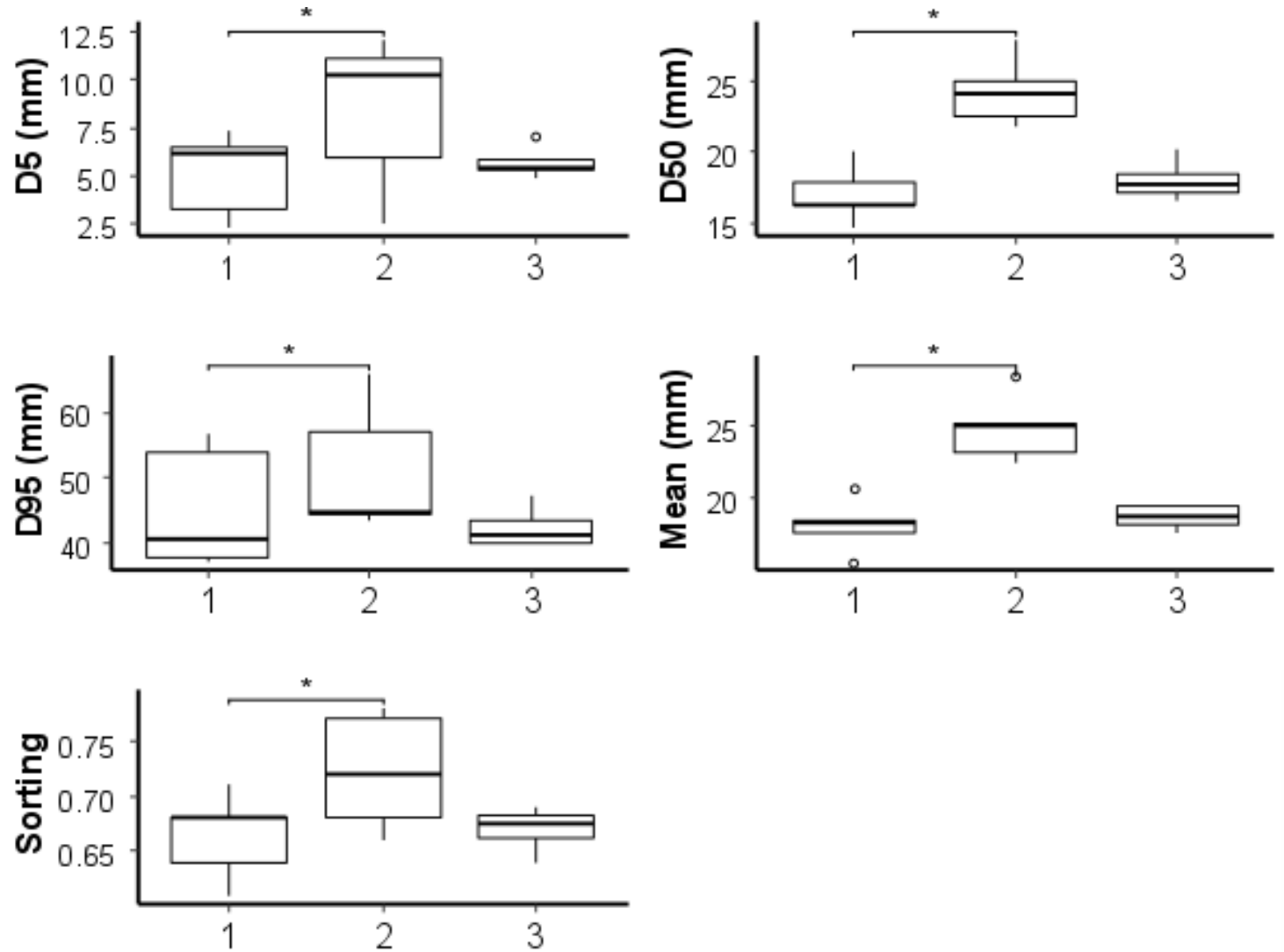

394

395 Figure 3 Surface percentiles and statistical parameters significantly affected by 396 treatment, pre-jetting (1), 24 hours post-jetting (2) and 12 months post-jetting (3) at the 397 riffle scale. Thin horizontal lines represent 10, 25, 85 and 90 percentiles. Thick black 398 horizontal lines, circles and asterisks represent medians, outliers and significant 399 relationships, respectively. 
400 At the patch scale, there was a significant effect of treatment and time interaction on D5

401 (GLMM; $P<0.01)$, D50 (LMM; $P<0.01)$, D95 (GLMM; $P<0.05)$, mean (LMM; $P<$ 402 0.01) and sorting parameters (LMM; $P<0.01$ ) (Table 2a). Compared to control patches, 403 the sediments of jetted patches one hour after jetting had significantly higher $D 5, D 50$, 404 D95 and mean values, although differences in sorting, skewness and kurtosis values 405 were not significantly different (Table 2b; Figure 4). After 3 months, only the D5 406 significantly differed from the control patches, while other percentiles showed no 407 significant differences between control and treated patches (Table 2b; Figure 4). 408 Furthermore, none of the percentiles or statistical parameters were significantly 409 different after 9 months when comparing data derived from control and treatment 410 patches (Figure 4).

411

412

413

414

415

416

417

418

419

420

421

422

423 
424 Table 2 Outputs from linear mixed models testing for differences in surface sediment 425 parameters between control and jetted patches: a) final models; and b) pairwise 426 comparisons; where: 1) 1 hour post-jetting; 2) 3 months post-jetting; and 3) 9 months 427 post-jetting. Each repeated sample was specified as a random effect on the intercept. 428 Mean differences are from estimated least-square means (difference significant at * $P<$ 4290.05 and $* * P<0.01)$.

430 a)

\section{Final models:}

D5 Treatment x Time + (1|Sample) (family - Gaussian (link-log); Laplace approximation, AIC $=-251.84 ; \log$ likelihood $\left.=-117.92 ; P<0.01^{* *}\right)$

D50 Treatment $\mathrm{x}$ Time $+(1 \mid$ Sample $)\left(\right.$ AIC $=303.31 ; \log$ likelihood $\left.=-143.66 ; P<0.01^{* *}\right)$

D95 Treatment x Time + (1|Sample) (family - Gaussian (link-log); penalized quasilikelihood; AIC $=$ NA; log likelihood $=$ NA; $\left.P<0.05^{*}\right)$

Mean $\sim$ Treatment $x$ Time $+(1 \mid$ Sample $)\left(\right.$ AIC $=301.99 ; \log$ likelihood $\left.=-143.00 ; P<0.01^{* *}\right)$

Sorting $\sim$ Treatment $\mathrm{x}$ Time $+(1 \mid$ Sample $)\left(\right.$ AIC $=-142.47 ; \log$ likelihood $\left.=79.14 ; P<0.01^{* *}\right)$

Skewness $\sim$ Treatment $x$ Time $+(1 \mid$ Sample $)($ AIC $=-68.92 ; \log$ likelihood $=42.46 ; P>0.05)$

Kurtosis $\sim$ Treatment $\mathrm{x}$ Time $+(1 \mid$ Sample $)($ AIC $=-220.28$; log likelihood $=118.14 ; P>0.05)$

431

432

433

434

435

436

437

438 
b)

\begin{tabular}{llll}
\hline Metric & Mean difference & & \\
& $\mathbf{1}$ & 2 & 3 \\
& & & \\
\hline D5 & $-0.45 \pm 0.13, P<0.01^{* *}$ & $-0.81 \pm 0.32, P<0.05^{*}$ & $-0.41 \pm 0.61, P>0.05$ \\
& & & \\
D50 & $-4.23 \pm 1.89, P<0.05^{*}$ & $-0.78 \pm 1.89, P>0.05$ & $-0.002 \pm 1.89, P>0.05$ \\
D95 & $-0.20 \pm 0.06, P<0.01^{* *}$ & $-0.01 \pm 0.09, P>0.05$ & $0.03 \pm 0.08, P>0.05$ \\
Mean & $-5.15 \pm 1.77, P<0.01^{* *}$ & $-0.97 \pm 1.77, P>0.05$ & $-0.16 \pm 1.77, P>0.05$ \\
Sorting & $-0.03 \pm 0.03, P>0.05$ & $-0.02 \pm 0.03, P>0.05$ & $-0.03 \pm 0.03, P>0.05$ \\
\hline
\end{tabular}

440

441

442

443

444

445

446

447

448

449

450

451

452

453

454 

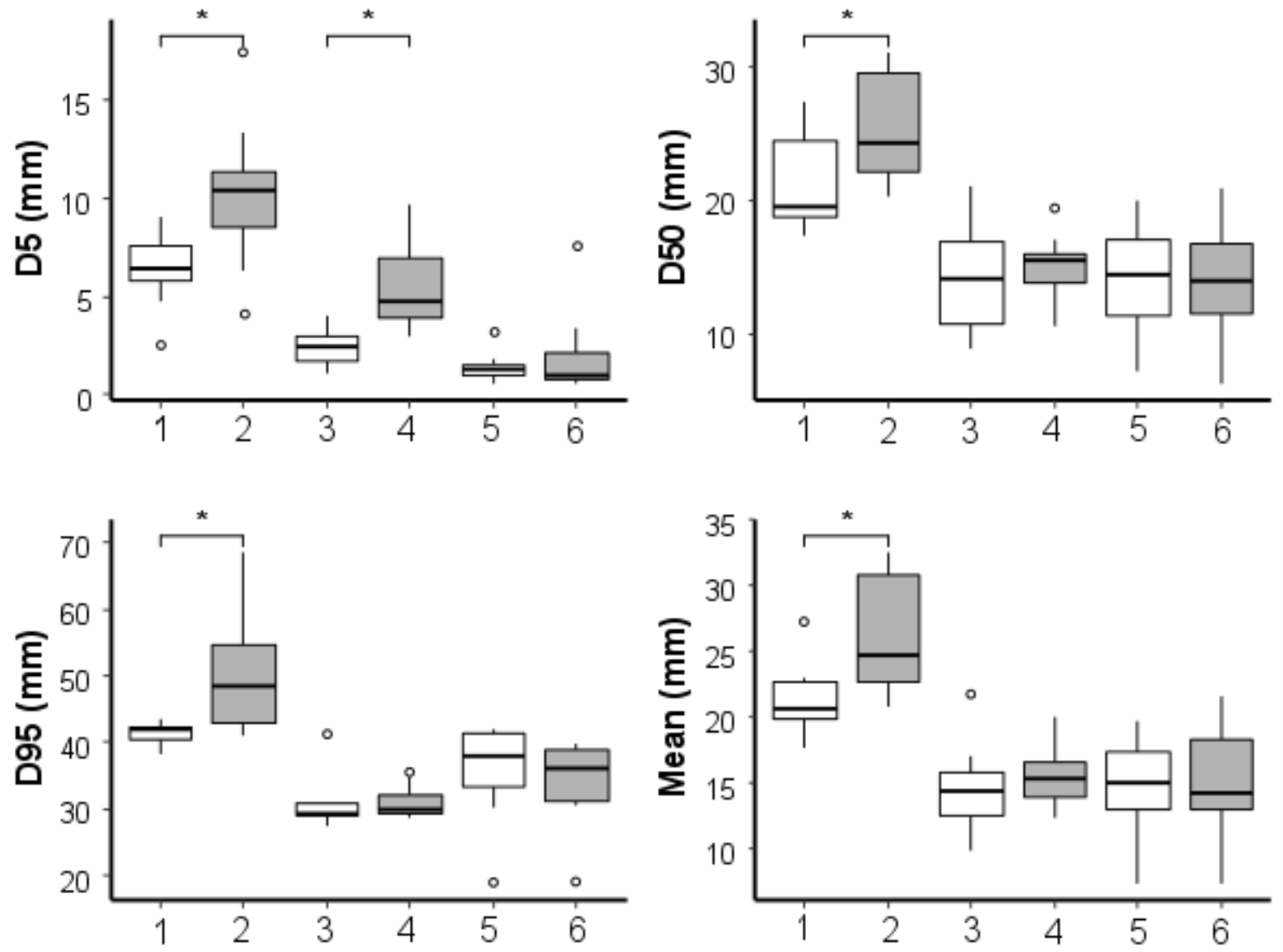

455

456 Figure 4 Surface percentiles and statistical parameters significantly affected by 457 treatment, 1 hour post-jetting $(1,2), 3$ months post-jetting $(3,4)$ and 9 months post458 jetting $(5,6)$ at control (white boxes) and treated patches (grey boxes). Thin horizontal 459 lines represent 10, 25, 85 and 90 percentiles. Thick black horizontal lines, circles and 460 asterisks represent medians, outliers and significant relationships, respectively. 

scales

470 At the riffle scale, gravel jetting significantly affected the subsurface D5 (GLMM; $P<$ 471 0.05), sand content (GLMM; $P<0.05)$ and silt content (GLMM; $P<0.01)$ (Table 3a). 472 In contrast, $D 50$ (LMM; $P>0.05)$, D95 (GLMM; $P>0.05)$ mean (LMM; $P>0.05$ ), 473 sorting (LMM; $P>0.05)$, skewness (LMM; $P>0.05)$ and kurtosis (LMM; $P>0.05)$ 474 values were not significantly altered by gravel jetting (Table 3a; Figure 5).

475

476 Riffle-scale assessments of substrate condition 24 hours after the jetting phase showed 477 an increase in D5 and decreases in subsurface sand and silt content, which indicate a 478 reduction in the fine sediment content of the bed material (Table 3b; Figure 5). The 479 longevity of this impact was short-lived, and conditions after 12 months were not 480 significantly different from pre-jetting conditions (Table 3b; Figure 5).

481

482 At the patch scale, gravel jetting did not significantly impact upon subsurface sediment 483 composition; there were no differences in grain size distribution parameters between 484 treatment and control patches 1 hour after the jetting phase (Table 4).

485

486

487

488

489

490

491 
492 Table 3 Outputs from linear mixed models testing for differences at the riffle scale

493 in subsurface sediment parameters: a) final models; and b) pairwise comparisons, 494 where: 1) pre- and 24 hours post-jetting; and 2) pre- and 12 month post-jetting. 495 Site and sample were random effects on the intercept. Mean differences are from 496 estimated least-square means (difference significant at $* P<0.05$ and $* * P<$ $497 \quad 0.01)$

498 a)

\section{Final models:}

D5 Treatment + (1|Site) + (1|Sample) (family - Gaussian (link-log); Laplace approximation, AIC $=-14.0 ; \log$ likelihood $\left.=13.0 ; P<0.05^{*}\right)$

D50 Treatment $+(1 \mid$ Site $)+(1 \mid$ Sample $)($ AIC $=656.84 ; \log$ likelihood $=-322.42 ; P>0.05)$

D95 Treatment + (1|Site) + (1|Sample) (family - Gaussian (link-log); penalized quasilikelihood; AIC = NA; $\log$ likelihood $=$ NA; $P>0.05)$

Mean $\sim$ Treatment $+(1 \mid$ Site $)+(1 \mid$ Sample $)($ AIC $=612.23 ; \log$ likelihood $=-300.12 ; P>0.05)$

Sorting $\sim$ Treatment $+(1 \mid$ Site $)+(1 \mid$ Sample $)($ AIC $=226.74 ; \log$ likelihood $=119.37 ; P>0.05)$

Skewness $\sim$ Treatment $+(1 \mid$ Site $)+(1 \mid$ Sample $)($ AIC $=149.03 ; \log$ likelihood $=-68.52 ; P>$ $0.05)$

Kurtosis $\sim$ Treatment $+(1 \mid$ Site $)+(1 \mid$ Sample $)($ AIC $=-529.82 ; \log$ likelihood $=270.91 ; P>0.05)$

Sand content $\sim$ Treatment $+(1 \mid$ Site $)+(1 \mid$ Sample $)+(1 \mid$ Sample_ID) (family - binomial (linklogit); AIC = 1930.60; log likelihood = -959.30; $\left.P<0.05^{*}\right)$

Silt content $\sim$ Treatment $+(1 \mid$ Site $)+(1 \mid$ Sample $)+(1 \mid$ Sample_ID) (family - binomial (linklogit); AIC = 782.30; log likelihood $=-385.10 ; P<0.01^{* *}$ )

499

500

501

502 
b)

\begin{tabular}{lll}
\hline Metric & \multicolumn{2}{l}{ Mean difference } \\
\cline { 2 - 3 } & $\mathbf{1}$ \\
\hline D5 & $-0.32 \pm 0.11, P<0.01^{*^{*}}$ & $\mathbf{2}$ \\
Sand content & $0.43 \pm 0.16, P<0.05^{*}$ & $0.21 \pm 0.13, P>0.05$ \\
Silt content & $0.73 \pm 0.15, P<0.01^{* *}$ & $0.33 \pm 0.18, P>0.05$ \\
\hline
\end{tabular}

504

505

506

507

508

509

510

511

512

513

514

515

516

517

518

519

520 
521 Table 4 Outputs from linear and mixed linear models testing for differences in 522 subsurface sediment parameters between control and jetted patches 1 hour post523 jetting. Mean differences are from estimated least-square means (difference 524 significant at $* P<0.05$ and $* * P<0.01)$.

\section{Final models:}

D5 Treatment (family - Gaussian (link-log); $\left.\chi^{2}=1.93 ; P>0.05\right)$

$\mathrm{D} 50 \sim$ Treatment $\left(\mathrm{F}(16)=0.67 ; \mathrm{R}^{2}=0.04 ; P>0.05\right)$

D95 Treatment + (1|Sample_ID) (family - Gaussian (link-log); penalized quasilikelihood;

AIC $=$ NA; log likelihood $=$ NA; $P>0.05)$

Mean $\sim$ Treatment $\left(\mathrm{F}(16)=1.11 ; \mathrm{R}^{2}=0.06 ; P>0.05\right)$

Sorting $\sim$ Treatment $\left(\mathrm{F}(16)=3.89 ; \mathrm{R}^{2}=0.20 ; P>0.05\right)$

Skewness $\sim$ Treatment $\left(\mathrm{F}(16)=3.76 ; \mathrm{R}^{2}=0.19 ; P>0.05\right)$

Kurtosis $\sim$ Treatment $\left(\mathrm{F}(16)=4.02 ; \mathrm{R}^{2}=0.20 ; P>0.05\right)$

Sand content $\sim$ Treatment $+($ (1|Sample_ID) (family - binomial (link-logit); AIC = 280.70; log likelihood $=-137.40 ; P>0.05)$

Silt content $\sim$ Treatment $+($ (1|Sample_ID) $($ family - binomial (link-logit); AIC = 113.40; log likelihood $=-53.70 ; P>0.05)$

Organic matter content $\sim$ Treatment (family - binomial (link-logit); $\chi^{2}=2.20 ; P>0.05$ ) 

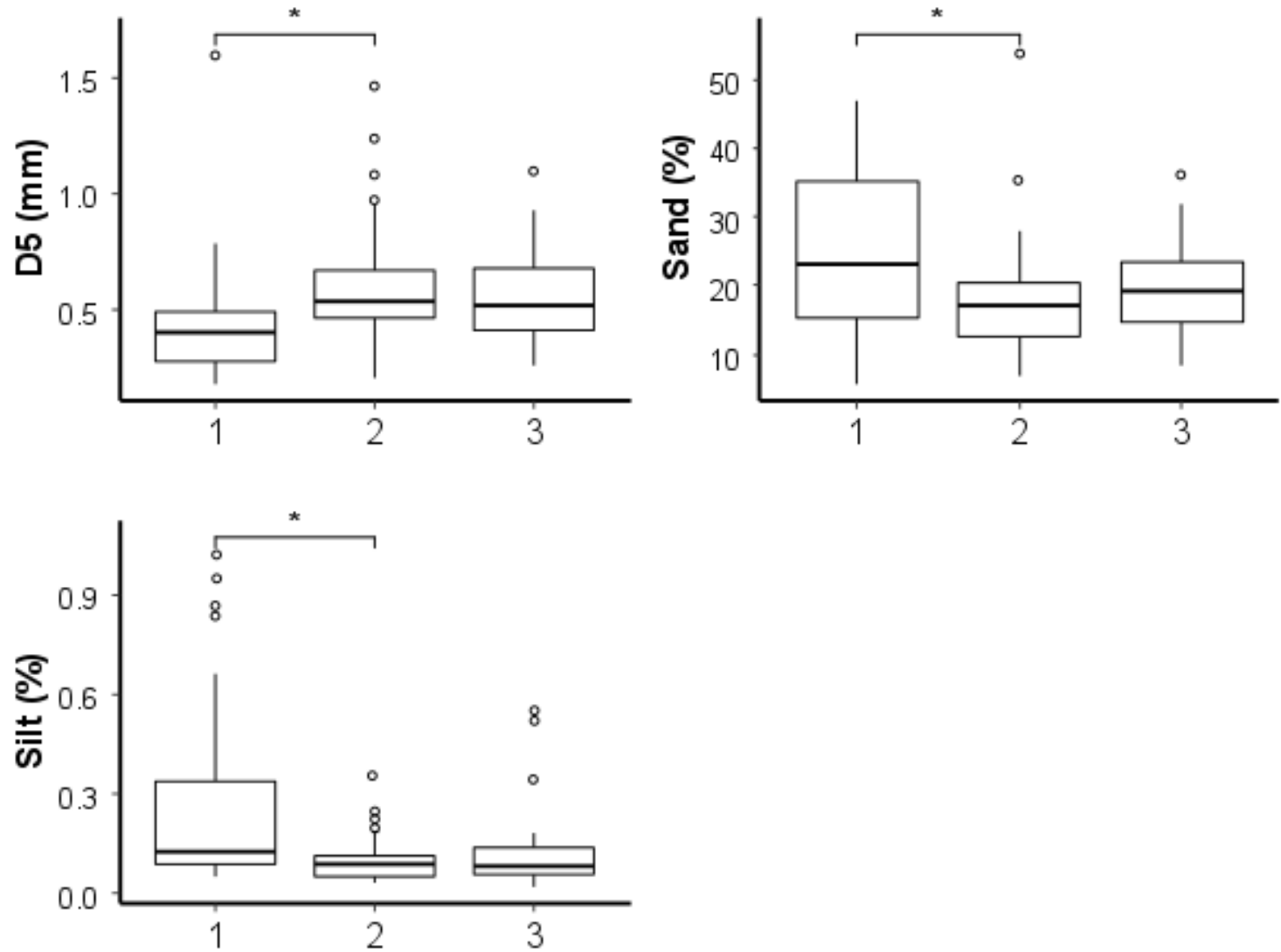

534 Figure 5 Subsurface percentiles, statistical parameters and sand and silt content significantly affected by treatment, pre-jetting (1), 24 hours post-jetting (2) and 12 months post-jetting (3) at the riffle scale. Thin horizontal lines represent 10, 25, 85 and 90 percentiles. Thick black horizontal lines, circles and asterisks represent medians, outliers and significant relationships, respectively. the patch scale

542 Data derived from bedload samples revealed that gravel jetting mobilised bed material.

543 The mean mass of displaced sediment from each treated patch was $7.04 \pm 2.37 \mathrm{~kg}$, with 544 no mobility observed or quantified under control conditions (Table 5). In general, 
545 displaced sediments predominately consisted of poorly-sorted gravels and sand, with

546 leptokurtic distributions that were strongly skewed towards finer grain sizes (Table 5).

547 The majority of sediment mobilised from the bed during jetting was sand $(60.31 \pm 2.91$

$548 \%$; Table 5).

549

550 Table 5 Quantity and composition of mobile sediment, washed from the bed during

551 patch-scale jetting. Patch mean values $(n=9 ; \pm S E)$.

\begin{tabular}{llc}
\hline Metric & Value & 552 \\
\hline$D 5(\mathrm{~mm})$ & $0.29 \pm 0.02$ & 553 \\
$D 50(\mathrm{~mm})$ & $1.68 \pm 0.47$ & \\
$D 95(\mathrm{~mm})$ & $30.05 \pm 8.33$ & 554 \\
Mean (mm) & $3.51 \pm 0.41$ & 555 \\
Sorting & $0.36 \pm 0.03$ & \\
Skewness & $1.72 \pm 0.36$ & 556 \\
Kurtosis & $0.17 \pm 0.02$ & 557 \\
Sand (\%) & $60.31 \pm 2.91$ & \\
Silt (\%) & $0.14 \pm 0.02$ & 558 \\
Organic matter content (\%) & $1.59 \pm 0.20$ & 559 \\
Amount of sediment/patch (kg) & $7.04 \pm 2.37$ & \\
\hline
\end{tabular}

561

562 4. Discussion

563 Results from this in-situ experiment revealed that gravel jetting had a significant

564 coarsening effect on the surface gravels of the river at riffle and patch scales. Jetting

565 caused a reduction in the fines content of subsurface sediments at the riffle scale, and 
most other grain size parameters were unaffected. When applied at patch scales, there were no impacts of jetting on the subsurface bed material. These quantified effects in both surface and subsurface sediments diminished at the riffle scale 12 months after gravel jetting. Additionally, no significant differences were detected for most assessed properties of surface sediments 3 months post-jetting at the patch scale. Significant quantities of fine sediments, largely consisting of sand, were purged from the bed during jetting and transported downstream.

574 Analysis of surface grain-size distributions during both riffle and patch scale assessments indicated that gravel jetting had a significant impact on the composition of surface spawning gravels by displacing finer sediments, which resulted in coarser, better-sorted sediments (significantly increased percentiles, mean and sorting). In comparison, Sepulveda et al. (2015) identified fewer significant alterations in surface percentiles (D50, D84) as a function of gravel restoration via modified suction dredging in North America, with a decrease in surface particle sizes following restoration. However, suction dredging is a more invasive technique, which could explain observed reductions in particle sizes in that study.

Subsurface grain-size distributions at riffle and patch scales were not affected as strongly as the surface, with a reduction in fines content at the riffle scale, but no change in D50 or mean grain size at both scales. In contrast, Pulg et al. (2013) measured significant change in the mean grain size following restoration via bucket excavators in Germany, while Pander et al. (2015) reported an increase in the geometric mean particle diameter of subsurface sediments at 4 out of 6 sites following gravel-cleaning 
operations in Germany, with an overall non-significant effect. Impacts of increased

591 subsurface grain sizes on lithophilic fish species during incubation vary between

592 studies. While some report increased survival rates related to decreased fine sediment

593 content and increased oxygen concentration (Pulg et al. 2013), others find limited

594 benefits of increased grain sizes for egg survival of lithophilic fish species (Mueller et

595 al. 2014). As our study implied no change in subsurface mean grain size or D50,

596 benefits for lithophilic species dependent on the subsurface zone are expected to be

597 minor following gravel jetting, at least based on the quantitative evidence presented 598 here.

599

600 For subsurface sediments, fines content was the only parameter influenced by gravel 601 jetting at the riffle scale, as indicated by significant increases in the $D 5$ and decreases in 602 sand and silt content. Other studies of gravel cleaning have recorded similar decreases 603 in fine sediment content (e.g. Meyer et al. 2008; Pulg et al. 2013; Sepulveda et al. 2015) 604 and similar success has also been associated with gravel additions (Sarriquet et al. 605 2007). However, despite the reduction in fines caused by jetting, the amount of 606 subsurface sand in our study riffles on the River Great Ouse (17.7 \%) remained above 607 recommended levels; for example, they were above the $15 \%$ threshold thought to 608 detrimentally affect the early development of salmonid fishes (Kemp et al. 2011; 609 Kondolf 2000; O’Connor and Andrew 1998).

610

611 The detected difference between riffle and patch-scale jetting effects on the subsurface 612 sediments is potentially the result of either variability in pre-treatment site conditions 613 between the two experiments or the size of the treated areas. Firstly, while every effort 
614 was made to select comparable sites at the patch scale, sites at the riffle scale contained

615 substrates with different fines contents that could have impacted upon our results

616 (Pander et al. 2015). For example, the different sites used during the riffle-based work

617 each maintained substrates with high sand and silt contents, whereas substrates at sites

618 utilised during the patch-scale component had, in general, lower silt and sand contents.

619 High standard deviations for fines content prior to gravel jetting at the riffle, relative to

620 patch scale, further support this reasoning and imply high variability between the sites

621 selected for riffle-scale experimentation. This confirms the importance of local site

622 dynamics in shaping natural grain-size distributions that would therefore impact upon

623 the efficacy of investigated restoration techniques (Pander et al 2015; Pulg et al. 2013).

624

625 Importantly, measured changes in surface and subsurface sediments at the riffle scale

626 persisted for less than a year, which is consistent with previous studies (e.g. Meyer et al.

627 2008; Pander et al. 2015; Rubin et al. 2004). For example, dredging and redistribution

628 of gravels was found successful at removing fines from sediments in the River Sieg,

629 Germany, but the effects lasted only five months (Meyer et al. 2008). Sternecker et al.

630 (2013b) reported improvements in hyporheic water conditions and subsurface sediments

631 lasting for at least three months following restoration via substratum excavation in the

632 River Moosach, Germany, but the limited duration of the study prohibited further

633 assessment. Effects of gravel replenishment and fine sediment removal, using flow

634 deflectors and sediment traps on egg-to-emergence survival rates in a small stream in

635 Gotland, Sweden, were positive and significant but lasted less than a year (Rubin et al.

636 2004). Different methods of substratum restoration assessed by Pander et al. (2015) in

637 Germany only impacted upon physicochemical substratum quality for less than one 
638 year. However, as none of the investigated techniques were gravel jetting, this study is

639 the first to quantify the longevity of effects for this method and confirm that its impact

640 is equally short-lived.

641

642 The amount of sediment removed from the bed during patch-scale jetting was

643 significant and extrapolation to the riffle scale suggests that on average, almost 1 tonne

644 of sediment per site, consisting mainly of sand, would have been mobilised if riffle-

645 scale jetting had been employed. This could benefit subsequent rates of egg-to-

646 emergence and larval survival, as high concentrations of sand within sediments can trap

647 fines and therefore detrimentally impact upon life within the egg pocket (Levasseur et

648 al. 2006; Pulg et al. 2013; Sear et al. 2016). Additionally, gravel jetting loosens fluvial

649 substrates, likely reorganising stable, water-worked grains into random arrangements

650 and positions of relative instability. It is possible these structural changes, alongside

651 reductions in consolidating fine sediments, could reduce critical entrainment thresholds

652 and increase bed mobility, particularly under high flow conditions (Buffington et al.

653 2004; Powell 1998; Wilcock and McArdell 1997). It is then possible that scour depths

654 would be increased (Montgomery el al. 1996; Montgomery et al. 1999) and so,

655 potentially, the reproductive success of shallow-spawning lithophils. Additionally,

656 jetting of substrata with high proportions of sand led to downstream sediment

657 displacement of predominantly sand-sized material, which could deposit in clean

658 gravels downstream, with negative implications for habitats there (Pander et al. 2015).

659 Although quantification of suspended sediment fluxes were beyond the scope of the

660 study observations of suspended sediment plumes during jetting suggested the release of

661 suspendable particles and their downstream displacement under baseflow conditions. 
662 Mobilisation of these sediments could have significant consequences, particularly when

663 restoring large areas of river bed or fines-rich sediments.

664

665 It is well established that low fines content in spawning gravels are a prerequisite for

666 successful salmonid spawning, given their construction of redds in which eggs are

667 buried for extended periods during winter and spring (e.g. Kemp et al. 2011). In

668 contrast, there is limited knowledge on how gravel-spawning, non-salmonid fishes are

669 impacted by elevated fines content in spawning substrates. Inferences that the detected

670 impacts for salmonid fishes might be similar for other fishes are complicated due to

671 differing phenology and spawning strategies. For example, the spawning times of

672 riverine cyprinid fishes tend to be late spring and/ or early summer, when river flows are

673 reduced and thus impacts of fines in spawning gravels could be magnified due to

674 ambient oxygen levels being relatively low. However, unlike salmonid fishes, these

675 species rarely build extensive nests, instead using shallow depressions or depositing

676 eggs within surface gravel interstices (Balon 1975; Kottelat and Freyhof 2007). Eggs

677 and larvae spend less time within gravels, especially as the warmer temperatures help

678 minimise the time between egg deposition and emergence. Thus, the impacts of

679 substrate fines might be limited. Even though the reductions in fine sediment achieved

680 by jetting are short-lived, the technique might therefore be beneficial for non-salmonid

681 fishes, provided it is completed just prior to spawning aggregations and activities. This

682 would need balancing against the potential for damage to downstream habitats caused

683 by fine sediment displacement. Moreover, spawning of cyprinid fishes is asynchronous,

684 thus jetting activities to benefit a late-spawning species, such as B. barbus, could

685 coincide with reproductive activities of an earlier spawning species, such as Leuciscus 
686 leuciscus (Maitland and Linsell 2006). Thus, careful planning around the phenology of 687 the fishes within the local community would be required to deliver optimal benefits.

688

689 Local interventions, such as gravel jetting, therefore do not deliver long-term or 690 straightforward solutions to fine sediment ingress, with potential negative implications 691 for downstream habitats and biota. Transferability of these data to other systems should 692 be considered with care, given differences in geomorphological conditions and fish communities. Nevertheless, there remains some potential for applying gravel jetting to

694 restore habitats of shallow spawners, particularly if completed just prior to spawning 695 over riffle scales at fines-rich sites, where only a short-term impact (lasting less than 3 696 months) is required. To increase longevity of jetting effects, flow deflectors could be 697 utilised post-jetting to enhance flows over restored areas, limiting fines ingress and 698 potentially maintaining post-jetting conditions for longer periods. This is speculative but could be tested in future studies. As an alternative, modified suction dredges could be used to remove rather than mobilise fine sediments from the river bed, avoiding 701 potentially detrimental ecological impacts of jetting and fines mobilisation (Sepulveda 702 et al. 2015). Other, potentially more sustainable localised actions have been suggested, such as creation of off-channel settling reservoirs and buffer zones to protect river banks from erosion and livestock (Hendry et al. 2003), but these typically influence ambient conditions across broad spatial scales, and can rarely be used to target localised issues.

706 At the largest scale, catchment scale changes in land management practices remain the 707 most effective solutions for dealing with excessive sedimentation in freshwater systems 708 (Hendry et al. 2003; Honea et al. 2009; Pulg et al. 2013), because they address the cause 709 of sedimentation in rivers, rather than treat the local 'symptoms'. To be effective, 
710 determination of fine sediment sources within catchments and their overall

711 contributions to sediment fluxes are required (Collins and Walling 2007a, 2007b; Naura

712 et al. 2016). However, these actions are often costly, time-consuming and not feasible

713 without substantial policy changes. Therefore, it is particularly important to investigate

714 the specific fine-sediment tolerances of eggs and larvae of fishes other than salmonids,

715 in both field and controlled conditions. Such investigations should provide benchmark

716 data for river managers to assess whether changes in sediment composition are a

717 function of restoration interventions and would deliver spawning and recruitment

718 benefits for the target fish species.

720 This then raises the issue of how restoration techniques can be better utilised in the conservation of fish spawning habitats conservation. Approximately $5-70 \mathrm{USD} / \mathrm{m}^{2}$ is spent on substrate improvements (e.g. gravel addition and cleaning), while placement of

723 in-stream structures costs between 119 and $190 \mathrm{USD} / \mathrm{m}^{2}$ (Cramer 2012) or around 20

724000 USD per project in the USA (Bernhardt et al. 2005). Despite this expenditure, 725 knowledge on the efficacy and impacts of the methods remain poorly quantified. 726 Correspondingly, it is recommended that future research has a focus on two areas.

727 Firstly, there is a need to investigate the impacts of a wide range of gravel restoration 728 methods, utilising appropriate experimental designs, degrees of replication and post729 restoration monitoring, that aim to build a more complete picture of the net effects of 730 different restoration techniques through time and space. A current lack of quantitative 731 evidence on the efficacy of restoration techniques makes selection of impactful methods 732 difficult. Secondly, cost-benefit analyses of restoration projects are required that cover a 733 range of freshwater habitats and biota, and incorporate environmental impact and 
734 resource requirements. Collectively, these will assist selection of the optimal restoration 735 methods to be applied in specific rivers.

736

\section{5. Acknowledgments}

738 This work was supported by a studentship funded by the Environment Agency and 739 Barbel Society, UK.

740

741

\section{References}

742 Arlinghaus, R., Wolter, C., 2003. Amplitude of ecological potential: chub Leuciscus 743 cephalus (L.) spawning in an artificial lowland canal. J. Appl. Ichthyol. 19 (1), 52-54. 744 doi: 10.1046/j.1439-0426.2003.00343.x.

745 Balon, E.K., 1975. Reproductive guilds of fishes: a proposal and definition. J. Fish. Res. 746 Board. Can. 32 (6), 821-864. doi: 10.1139/f75-110.

747 Banarescu, P.M., Bogutskaya, N.G., 2003. The Freshwater Fishes of Europe;

748 Cyprinidae 2, part II: Barbus. AULA-Verlag GmbH, Wiebelsheim.

749 Bašić, T., Britton, J.R., 2016. Characterising the trophic niches of stocked and resident 750 cyprinid fishes: consistency in partitioning over time, space and body sizes. Ecol. Evol. $751 \quad 6$ (14), 5093-5104. doi: 10.1002/ece3.2272.

752 Bates, D.M., 2010. lme4: Mixed-effects modelling with R. Springer, USA.

753 Bates, D.M., Maechler, M., Bolker, B., Walker, S., 2015. Fitting Linear Mixed-Effects 754 Models Using lme4. J. Stat. Softw. 67 (1), 1-48. 
755 Bernhardt, E.S., Palmer, M., Allan, J.D., Alexander, G., Barnas, K., Brooks, S., Carr, J., 756 Clayton, S., Dahm, C., Follstad-Shah, J., Galat, D., 2005. Synthesizing U. S. river 757 restoration efforts. Science. 308 (5722), 636-637. doi: 10.1126/science.1109769.

758 Bolker, B.M., Brooks, M.E., Clark, C.J., Geange, S.W., Poulsen, J.R., Stevens, M.H. H., 759 White, J.-S.S. (2009). Generalized linear mixed models: a practical guide for ecology 760 and evolution. Trends Ecol. Evol. 24 (3), 127-135. doi: 10.1016/j.tree.2008.10.008.

761 Bond, N.R., Lake, P.S., 2003. Characterizing fish-habitat associations in streams as the 762 first step in ecological restoration. Austral. Ecol. 28 (6), 611-621. doi: 10.1046/j.1442763 9993.2003.t01-1-01317.x.

764 Britton, J. R., Pegg, J., 2011. Ecology of European Barbel B. barbus: Implications for 765 river, fishery, and conservation management. Rev. Fish. Sci. 19, 321-330. doi: $766 \quad 10.1080 / 10641262.2011 .599886$.

767 Bryce, S.A., Lomnicky, G. A., Kaufmann, P.R., 2010. Protecting sediment-sensitive 768 aquatic species in mountain streams through the application of biologically based 769 streambed sediment criteria. J. N. Am. Benthol. Soc. 29 (2), 657-672.

770 Buffington, J.M., Montgomery, D.R., Greenberg, H.M., 2004. Basin-scale availability 771 of salmonid spawning gravel as influenced by channel type and hydraulic roughness in 772 mountain catchments. Can. J. Fish. Aquat. Sci. 61 (11), 2085-2096. doi: 10.1139/f04773141.

774 Bunte, K., Abt, S. R., 2001. Sampling surface and subsurface particle-size distributions 775 in wadable gravel-and cobble-bed streams for analyses in sediment transport, 
776 hydraulics, and streambed monitoring. Department of Agriculture, Forest Service, 777 Rocky Mountain Research Station, Fort Collins, USA.

778 CEN, 2007. Characterization of waste - Determination of loss on ignition in waste, 779 sludge and sediments. CEN, Brussels.

780 Collins, A.L., Walling, D.E., 2007a. Sources of fine sediment recovered from the 781 channel bed of lowland groundwater-fed catchments in the UK. Geomorphology 88 (1), 782 120-138. doi: 10.1016/j.geomorph.2006.10.018.

783 Collins, A.L., Walling, D.E., 2007b. The storage and provenance of fine sediment on 784 the channel bed of two contrasting lowland permeable catchments, UK. River Res. 785 Appl. 23 (4), 429-450. doi: 10.1002/rra.992.

786 Cramer, M.L., 2012. Stream Habitat Restoration Guidelines. Washington Departments 787 of Fish and Wildlife, Natural Resources, Transportation and Ecology, Washington State 788 Recreation and Conservation Office, Puget Sound Partnership, and the U.S. Fish and 789 Wildlife Service, Olympia, Washington.

790 Dudgeon, D., Arthington, A.H., Gessner, M.O., Kawabata, Z.I., Knowler, D.J., 791 Lévêque, C., Naiman, R.J., Prieur-Richard, A.H., Soto, D., Stiassny, M.L., Sullivan, 792 C.A., 2006. Freshwater biodiversity: importance, threats, status and conservation 793 challenges. Biol. Rev. 81 (2), 163-182. doi: 10.1017/S1464793105006950.

794 Franssen, J., Lapointe, M., Magnan, P., 2014. Geomorphic controls on fine sediment 795 reinfiltration into salmonid spawning gravels and the implications for spawning habitat 796 rehabilitation. Geomorphology. 211, 11-21. doi: 10.1016/j.geomorph.2013.12.019. 
797 Garner, P., 2010. Habitat use by 0+ cyprinid fish in the River Great Ouse, East Anglia. 798 Freshwater Forum. 8 (1), 2-27.

799 Geist, J., 2011. Integrative freshwater ecology and biodiversity conservation. Ecol. 800 Indic. 11 (6), 1507-1516. doi: 10.1016/j.ecolind.2011.04.002.

801 Giller, P.S., 2005. River restoration: seeking ecological standards. Editor's introduction. 802 J. Appl. Ecol. 42 (2), 201-207. doi: 10.1111/j.1365-2664.2005.01020.x.

803 Hancock, P.J., 2002. Human impacts on the stream-groundwater exchange zone. 804 Environ. Manage. 29 (6), 763-781. doi: 10.1007/s00267-001-0064-5.

805 Hassan, M.A., Tonina, D., Buxton, T.H., 2015. Does small-bodied salmon spawning 806 activity enhance streambed mobility? Water Resour. Res. 51 (9), 7467-7484. doi: 807 10.1002/2015WR017079.

808 Hendry, K., Cragg-Hine, D., O’Grady, M., Sambrook, H., Stephen, A., 2003. 809 Management of habitat for rehabilitation and enhancement of salmonid stocks. Fish. 810 Res. 62, 171-192. doi: 10.1016/S0165-7836(02)00161-3.

811 Honea, J.M., Jorgensen, J.C., McClure, M.M., Cooney, T.D., Engie, K., Holzer, D.M. 812 and Hilborn, R., 2009. Evaluating habitat effects on population status: influence of 813 habitat restoration on spring-run Chinook salmon. Freshwater Biol. 54 (7), 1576-1592. 814 doi: 10.1111/j.1365-2427.2009.02208.x.

815 Kemp, P., Sear, D., Collins, A., Naden, P., Jones, I., 2011. The impacts of fine sediment 816 on riverine fish. Hydrol. Process. 25 (11), 1800-1821. doi: 10.1002/hyp.7940. 
817 Kondolf, G.M., 2000. Assessing Salmonid Spawning Gravel Quality. T. Am. Fish. Soc. 818129 (1), 262-281. doi: 10.1577/1548-8659(2000)129<0262:ASSGQ>2.0.CO;2.

819 Kottelat, M., Freyhof, J., 2007. Handbook of European freshwater fishes. Publications 820 Kottelat, Switzerland.

821 Lapointe, M., Bergeron, N., Berube, F., Pouliot, M., Johnston, P., 2005. Interactive 822 effects of substrate sand and silt contents, redd-scale hydraulic gradients, and interstitial 823 velocities on egg-to-emergence survival of Atlantic salmon (Salmo salar). Can. J. Fish. 824 Aquat. Sci. 61 (12), 2271-2277. doi: 10.1139/f04-236.

825 Levasseur, M., Bergeron, N.E., Lapointe, M.F., Bérubé, F., 2006. Effects of silt and 826 very fine sand dynamics in Atlantic salmon (Salmo salar) redds on embryo hatching 827 success. Can. J. Fish. Aquat. Sci. 63 (7), 1450-1459. doi: 10.1139/f06-050.

828 Maitland, P.S, Linsell, K., 2006. Guide to freshwater fish of Britain and Europe. 829 Philip’s, London.

830 McManamay, R.A., Orth, D.J., Dolloff, C.A., Cantrell, M.A., 2010. Gravel addition as a 831 habitat restoration technique for tailwaters. N. Am. J. Fish. Manage. 30 (5), 1238-1257. 832 doi: 10.1577/M10-007.1.

833 McNeil, W.J., Ahnell, W.H., 1964. Success of pink salmon spawning relative to size of 834 spawning bed materials, Report no. 157. US Department of Interior, Fish and Wildlife 835 Service, Washington.

836 Melcher, A.H. and Schmutz, S., 2010. The importance of structural features for 837 spawning habitat of nase Chondrostoma nasus (L.) and barbel Barbus barbus (L.) in a 838 pre-Alpine river. River Systems, 19 (1), 33-42. doi: 10.1127/1868-5749/2010/019-0033. 
839 Merz, J.E., Ochikubo Chan, L.K., 2005. Effects of gravel augmentation on macro-

840 invertebrate assemblages in a regulated California river. River Res. Appl. 21 (1), 61-74.

841 doi: 10.1002/rra.819.

842 Meyer, C.B., 2003. The importance of measuring biotic and abiotic factors in the lower

843 egg pocket to predict coho salmon egg survival. J. Fish. Biol. 62 (3), 534-548. doi:

844 10.1046/j.1095-8649.2003.00039.x.

845 Meyer, E.I., Niepagenkemper, O., Molls, F., Spänhoff, B., 2008. An experimental 846 assessment of the effectiveness of gravel cleaning operations in improving hyporheic 847 water quality in potential salmonid spawning areas. River Res. Appl. 24 (2), 119-131. 848 doi: 10.1002/rra.1051.

849 Michel, C., Schindler Wildhaber, Y., Epting, J., Thorpe, K.L., Huggenberger, P., 850 Alewell, C., Burkhardt-Holm, P., 2014. Artificial steps mitigate the effect of fine 851 sediment on the survival of brown trout embryos in a heavily modified river. Freshwater 852 Biol. 59 (3), 544-556. doi: 10.1111/fwb.12284.

853 Montgomery, D.R., Beamer, E.M., Pess, G.R., Quinn, T.P., 1999. Channel type and 854 salmonid spawning distribution and abundance. Can. J. Fish. Aquat. Sci. 6 (3), 377-387. 855 doi: 10.1139/f98-181.

856 Montgomery, D.R., Buffington, J.M., Peterson, N.P., Schuett-Hames, D., Quinn, T. P., 857 1996. Stream-bed scour, egg burial depths, and the influence of salmonid spawning on 858 bed surface mobility and embryo survival. Can. J. Fish. Aquat. Sci. 53, 1061-1070. doi: 859 10.1139/f96-028. 
860 Morandi, B., Piégay, H., Lamouroux, N., Vaudor, L., 2014. How is success or failure in 861 river restoration projects evaluated? Feedback from French restoration projects. J. 862 Environ. Manage. 137, 178-188. doi: 10.1016/j.jenvman.2014.02.010.

863 Mueller, M., Pander, J., Geist, J., 2014. The ecological value of stream restoration 864 measures: an evaluation on ecosystem and target species scales. Ecol. Eng. 62, 129-139. 865 doi: 10.1016/j.ecoleng.2013.10.030.

866 Naura, M., Hornby, D.D., Collins, A.L., Sear, D.A., Hill, C., Jones, J.I., Naden, P.S., 867 2016. Mapping the combined risk of agricultural fine sediment input and accumulation 868 for riverine ecosystems across England and Wales. Ecol. Indic. 70, 209-221. doi: 869 10.1016/j.ecolind.2016.03.055.

870 Neal, C., Jarvie, H.P., Williams, R.J., Pinder, L.C.V., Collett, G.D., Neal, M., Bhardwaj, 871 L., 2000. The water quality of the Great Ouse. Sci. Total Environ. 251, 423-440. doi: 872 10.1016/S0048-9697(00)00420-4.

873 O'Connor, W.C.K., Andrew, T.E., 1998. The effects of siltation on Atlantic salmon, 874 Salmo salar L., embryos in the River Bush. Fisheries Manag. Ecol. 5 (5), 393-401. doi: $875 \quad$ 10.1046/j.1365-2400.1998.550393.x.

876 Ordnance survey, 2005. GB National Outlines, Scale 1:250000. 877 http://digimap.edina.ac.uk (accessed 29/04/16).

878 Ordnance survey, 2015. Strategi ${ }^{\circledR}$ Map, Upper part of the River Great Ouse, GB, Scale 879 1:250000. http://digimap.edina.ac.uk (accessed 29/04/16). 
880 Palm, D., Brännäs, E., Lepori, F., Nilsson, K., Stridsman, S., 2007. The influence of 881 spawning habitat restoration on juvenile brown trout (Salmo trutta) density. Can. J. 882 Fish. Aquat. Sci 64 (3), 509-515. doi: 10.1139/f07-027.

883 Palmer, M.A., Allan, J. D., Meyer, J., Bernhardt, E.S., 2007. River restoration in the 884 twenty-first century: data and experiential knowledge to inform future efforts. Restor. 885 Ecol. 15(3), 472-481. doi: 10.1111/j.1526-100X.2007.00243.x.

886 Palmer, M.A., Covich, A., Finlay, B., Gilbert, J., Hyde, K., Johnson, R., Kairesala, T., 887 Lake, P., Lovell, C., Naiman, R., Ricci, C., 1997. Biodiversity and ecosystem processes 888 in freshwater sediments. Ambio, 571-577.

889 Palmer, M.A., Menninger, H.L., Bernhardt, E., 2010. River restoration, habitat 890 heterogeneity and biodiversity: a failure of theory or practice? Freshwater Biol. 55 (s1), 891 205-222. doi: 10.1111/j.1365-2427.2009.02372.x.

892 Pander, J., Geist, J., 2013. Ecological indicators for stream restoration success. Ecol. 893 Indic. 30, 106-118. doi: 10.1016/j.ecolind.2013.01.039.

894 Pander, J., Mueller, M., Geist, J., 2015. A comparison of four stream substratum 895 restoration techniques concerning interstitial conditions and downstream effects. River 896 Res. Appl. 31 (2), 239-255. doi: 10.1002/rra.2732.

897 Pattison, I., Sear, D.A., Collins, A.L., Jones, J.I., Naden, P.S., 2015. Interactions 898 between fine-grained sediment delivery, river bed deposition and salmonid spawning 899 success. PIAHS. 367, 199-206. doi:10.5194/piahs-367-199-2015. 
900 Pinder, L.C.V., 1997. Research on the Great Ouse: overview and implications for 901 management. Regul. Rivers: Res. Manage. 13 (3), 309-315. doi: 10.1002/(SICI)1099902 1646(199705)13:3<309::AID-RRR460>3.0.CO;2-J.

903 Pinder, L.C.V., Marker, A.F.H., Mann, R.H.K., Bass, J.A.B., Copp, G.H., 1997. The 904 River Great Ouse, a highly eutrophic, slow-flowing, regulated, lowland river in eastern 905 England. Regul. Rivers: Res. Manage. 13 (3), 203-218. doi: 10.1002/(SICI)1099906 1646(199705)13:3<203::AID-RRR449>3.0.CO;2-F.

907 Pledger, A.G., Rice, S.P., Millett, J., 2014. Reduced bed material stability and increased 908 bedload transport caused by foraging fish: a flume study with juvenile Barbel (Barbus 909 barbus). Earth Surf. Process. Landf. 39, 1500-1513. doi: 10.1002/esp.3592 .

910 Pledger, A.G., Rice, S.P., Millett, J., 2016. Bed disturbance via foraging fish increases

911 bedload transport during subsequent high flows and is controlled by fish size and 912 species. Geomorphology, 253, 83-93. doi: 10.1016/j.geomorph.2015.09.021.

913 Powell, D.M., 1998. Patterns and processes of sediment sorting in gravel-bed rivers. 914 Prog. Phys. Geogr. 22 (1), 1-32.

915 Pulg, U., Barlaup, B.T., Sternecker, K., Trepl, L., Unfer, G., 2013. Restoration of 916 spawning habitats of brown trout (Salmo trutta) in a regulated chalk stream. River Res. 917 Appl. 29, 172-182. doi: 10.1002/rra.1594.

918 R Development Core Team, 2011. R: A language and environment for statistical 919 computing. R Foundation for Statistical Computing, Vienna, Austria. ISBN 3-900051920 07-0, URL http://www.R-project.org/. 
921 Rice, S.P., Church, M., 1996. Sampling surficial fluvial gravels: The precision of size 922 distribution percentile estimates. J. Sediment. Res. A. Sediment. Petrol. Process. 66 (3), 923 654-665. doi: 10.2110/jsr.66.654.

924 Rubin, J.F., Glimsäter, C., Jarvi, T., 2004. Characteristics and rehabilitation of the 925 spawning habitats of the sea trout, Salmo trutta, in Gotland (Sweden). Fisheries Manag. 926 Ecol. 11 (1), 15-22. doi: 10.1111/j.1365-2400.2004.00349.x.

927 Sarriquet, P.E., Bordenave, P., Marmonier, P., 2007. Effects of bottom sediment 928 restoration on interstitial habitat characteristics and benthic macro-invertebrate 929 assemblages in a headwater stream. River Res. Appl. 23 (8), 815-828. doi: $930 \quad 0.1002 /$ rra.1013.

931 Sear, D.A., Burke, N., Bateman, S., Jones, J.I., Collins, A.L., Hulin, A., Pattison, I., 932 Naden, P.S., 2016. Does fine sediment source as well as quantity affect salmonid 933 embryo mortality and development? Sci. Total Environ. 541, 957-968. doi: 934 10.1016/j.scitotenv.2015.09.155.

935 Sepulveda, A.J., Layhee, M., Sutphin, Z.A., Sechrist, J. D., 2015. Evaluation of a Fine 936 Sediment Removal Tool in Spring-fed and Snowmelt Driven Streams. Ecological Rest. 93733 (3), 303-315. doi: 10.3368/er.33.3.303.

938 Shackle, V.J., Hughes, S., Lewis, V.T., 1999. The influence of three methods of gravel 939 cleaning on brown trout, Salmo trutta, egg survival. Hydrol. Process. 13 (3), 477-486. 940 doi: 10.1002/(SICI)1099-1085(19990228)13:3<477::AID-HYP751>3.0.CO;2-\#. 
941 Sternecker, K., Cowley, D.E., Geist, J., 2013a. Factors influencing the success of 942 salmonid egg development in river substratum. Ecol. Freshw. Fish. 22 (2), 322-333. doi: 943 10.1111/eff.12020.

944 Sternecker, K., Wild, R., Geist, J., 2013b. Effects of substratum restoration on salmonid 945 habitat quality in a subalpine stream. Environ. Biol. Fish. 96 (12), 1341-1351. doi: 946 10.1007/s10641-013-0111-0.

947 Trask, P.D., 1932. Origin and Environment of Source Sediments of Petroleum. Gulf 948 Publishing Co, Houston, Texas.

949 Twine, K.G., 2013. Conservation of barbel (Barbus barbus) in the River Great Ouse. 950 Thesis (PhD). Univeristy of Hull.

951 Venables, W.N., Ripley, B.D., 2002. Modern Applied Statistics with S, fourth ed. 952 Springer, New York.

953 Wheaton, J.M., Pasternack, G.B., Merz, J.E., 2004a. Spawning habitat rehabilitation -I. 954 Conceptual approach and methods. Intl. J. River Basin Management. 2 (1), 3-20.

955 Wheaton, J.M., Pasternack, G.B., Merz, J. E., 2004b. Spawning habitat rehabilitation 956 II. Using hypothesis development and testing in design, Mokelumne River, California, 957 U.S.A. Intl. J. River Basin Management. 2 (1), 21-37.

958 Wilcock, P.R., McArdell, B.W., 1997. Partial transport of a sand/gravel 959 sediment. Water Resour. Res. 33 (1), 235-245. doi: 10.1029/96WR02672.

960 Wood, P.J., Armitage, P.D., 1997. Biological effects of fine sediment in the lotic 961 environment. Environ. Manage. 21 (2), 203-217. doi: 10.1007/s002679900019. 